\title{
小学校体育授業における「個人の進歩」を強調した教師の言葉かけが 児童の動機づけに及ぼす効果
}

\author{
Effect of a Teacher's Verbal Interaction Emphasizing Children's Personal Development \\ on Their Motivation in Elementary School Physical Education
}

\author{
長谷川 悦 示：Etsushi HASEGAWA
}

筑波大学大学院人間総合科学研究科: University of Tsukuba, Graduate School of Comprehensive Human Sciences, 1-1-1 Tennodai, Tsukuba, Ibaraki 305-8574, Japan

\begin{abstract}
The purpose of this study is to examine the effects of a teacher's verbal interaction emphasizing children's personal development and improvement on their motivation in physical education class through experimental iniervention. The subjects were 19 fourth grade elementary school children (10-11 years old) and one male elementary school teacher with 11 years teaching experience.

In the study, a non-intervention unit of 7 lessons of apparatus gymnastics was conducted in the first trimester. Then an intervention unit of 9 lessons of portball (a basketball-like game) was conducted in the second trimester, during which the teacher gave children positive verbal feedback about the student's personal development and improvement as much as possible. The teacher's protocol was recorded and his verbal interaction with children was recalled by the children after each lesson. The children's motivational variables included personal goal orientation and perceived class climate, satisfaction with, positive attitude toward, and perceived self-competence in physical education, all of which were measured before and after the intervention unit.

During the intervention unit the teacher gave positive verbal feedback about personal development and improvement more than during the non-intervention unit. The number of children who perceived peer interaction was increased concurrently with the number of children who perceived teacher interaction.

The more positive verbal feedback emphasizing on personal development and improvement the children perceived, the higher their scores on motivational variables were appropriately enhanced. They highly evaluated task oriented goal and mastery class climate as well as their satisfaction with, positive attitude toward, and perceived self-competence in physical education. On the other hand, they showed lower ego oriented goal and lower perception of performance class climate.

Characteristics of effective verbal interaction that is perceived by children were positive feedback emphasizing personal development and improvement related to motor skill learning, question-inductive feedback in reciprocal interaction, and feedback in the presence of peers.
\end{abstract}

Keywords: teacher's verbal interaction, motivation, experimental intervention, elementary school physical education 


\section{I. 問題の所在}

子ども達が学習しようとする際には、学習をする 動機や目標が存在する。例えば、学習それ自体に興 味があるから、より多くのことを身につけたいか ら、良い成績を取りたいから、親にほめられたいか ら、友達に負けたくないから、などである。

近年、子ども達がどのような目標に方向づけら れて学習するのかについての研究が活発に行われ ている。Nicholls (1984) やDweck (1992)、Amesほ か (1984, 1988)は、個人の思考や行為を、ある目 標達成のための合理的な振る舞いと見る理論を構 築している。この理論は、個人が設定する目標や その意味づけによって、目標を達成するための手 段、方法、過程が影響を受け、結果的に様々な行 動が生じたり維持されたりするという立場をと り、目標理論（goal theory）と呼ばれている。目 標理論では、学業やスポーツなどの達成行動の本 質的な目標は、自分自身の能力を明示することで あるとしている。そしてその能力を明示する方法 には、大きく分けて二つのタイプがあると言われ ている。一つは、課題目標志向で、自分自身の技 能上達や課題達成によって自己の有能さを知覚す るタイプであり、もう一つは、自我目標志向で、 他者との比較により自己の有能さを知覚する夕イ プである。これらの目標概念は、研究者によって 呼称が異なるものの、二つに大別された目標の内 容は概念的に類似したものとしてとらえられてい る(Dudaほか, 1989, 1992, 1995:伊藤, 1996,長谷川 ほか, 1999)。

またAmes ほか(1988)は、マスタリー目標とパ フォーマンス目標の二つの目標概念を提示し、子 どもが知覚する「授業の雲囲気 (class climate)」と いう状況的な変数の影響について述べている。す なわち、マスタリー目標が強調される雲囲気を知 覚した場合には、子どもは新しい技能を習得し、 課題を理解しょうとし、能力を少しでも高めよう とし、更に他者との比較ではなく、自分自身の目 標基準に照らして満足感を感じる。それに対し て、パフォーマンス目標が強調される雲囲気を知 覚した場合には、子どもの関心は、他者と比較し た時の自分の能力や自己の価値に向けられ、人よ り少ない努力で優れた結果を得、人から賞賛を受 けることが重要になるという（Treasure, 1997）。
長谷川・下田ほか(1998)と長谷川ほか(1999)で は、小学校体育授業における個人の目標志向性や 授業の雲囲気知覚が、満足感や能力の知覚に影響 を及ぼすことを質問紙調査によって明らかにして いる。すなわち、課題志向の目標やマスタリー雲 囲気知覚が高いほど、体育授業に対して肯定的な 態度を示し、自分の運動能力や満足感を高く評価 していた。また特に、自分の運動能力が低いと知 覚している児童が、課題目標志向やマスタリー需 囲気知覚が低く、反対に自我目標志向やパフォー マンス雲囲気知覚が高い場合、体育授業に対して 否定的で、授業に不安や退屈を強く感じていた。

このように、個人傾性的な変数としての目標志 向性と状況知覚的な变数としての授業の䨌囲気知 覚は、子ども達の動機づけに作用し、学習行動に 影響を及ばしていると考えられている。

Ames(1992)は、子ども達がどちらの目標を知覚 するかを左右する学習環境の条件として、課題と 学習活動のあり方 (課題構造)、権威と責任のあり 方 (権威構造)、評価と承認のあり方 (評価構造) の三つの次元を取り上げている。Amesは、それぞ れの次元について、好ましい動機づけパターンを 導く教授方略を具体的に提案している。まず、課 題構造では、学習活動の重要な側面に焦点を当て た課題、子ども達の興味を引く新奇性のある課 題、多種多様な課題、短期的な目標を設定し挑戦 することのできる課題を準備することを挙げてい る。次に、権威構造では、子ども達自身の意志決 定を援助したり、選択の機会を提供したり、自己 評価の技能を発達させるように援助することを挙 げている。さらに、子ども達の望ましい動機づけ パターンを導く評価構造の教授方略としてAmes (1992)が挙げているのは、(1)個々の子ども達の向 上、進歩、習熟に力を注ぐこと、(2)公式的に一般 的に評価するのではなく個別的に一人一人を評価 すること、(3)子ども達の努力を認めること、(4)子 ども達が自分で向上していく機会を与えること、 (5)間違いを学習の一部としてみることができるよ うに子ども達を勇気づけることを述べている。

評価構造が内発的動機づけに及ぼす効果をテー マとして鹿毛(1996)は、Deciほか(1991)の認知的 評価理論に依拠し、教室の教科授業を対象に一連 の研究を行っている。この中では、特に評価主体 
(教師などによって行われる他者評価と、学習者 自身によって行われる自己評価）と評価基準（個 人内評価、相対評価、絶対評価)(注1)のあり方を 問題にしている。評価構造が動機づけに及ぼす影 響については、成績評価の予告、競争状況、集団 に準拠して行われる相対評価などが内発的動機づ けを低下させることなどを示唆した。

一方、目標理論に基づき、学習評価が学習意欲 に影響する心理的プロセスを検討した研究におい ても、鹿毛の知見を裏付ける結果が得られてい る。Butler（1987，1988，1990，1992）によれば、 ランキングや評定、相対比較など、自己に焦点を 当てる情報は、自己の能力がどのように評価され るかということに当人の関心を向けさせ、課題の 遂行が自尊感情の高揚あるいは低下の回避のため の手段となり、課題それ自体への興味を低下させ てしまう。一方、課題の遂行に関する適切なコメ ントや到達度の情報を提供することは、当人の関 心を課題そのものに向けさせ、課題関与を促進す ることから、内発的動機づけを高めるという。

望ましい学習評価のあり方については、このよ うに、子ども達の「動機づけ」への影響を中心 に、教育心理学の分野で盛んに研究されてきた が、それらの知見の多くは教室で行われる授業を 対象に得られたものであった。では、グラウンド や体育館で技能習得の程度が露呈される体育授業 においてはどのような評価構造のもとで評洒情報 が子ども達に伝えられているだろうか。

体育授業は達成行動の状況が周囲の目にさらさ れ、他者からの情報が与えられやすい環境にあるこ とを特徵とする。評価構造の伝達媒介として中心と なるのは教師の言葉かけなどの教授行動であり、そ れによって、評価の情報が学習者に与えられる。し たがって、教師の言葉かけ（verbal interaction）は、 体育の授業における評価構造を強く規定し、子ど も達の動機づけや学習活動に直接的に作用すると 考えられる。

体育科教育学の分野で、高橋ほか (1996，2003) は、小学校の体育授業における教師行動を分析 し、更に教師行動のあり方と子どもによる形成的 授業評価との関係を一連の研究で検証している。 この中で、個々の子どもに対する教師の言葉か け、特に、肯定的なフィードバックや矯正的
フィードバック、励ましを多く与えることが形成 的授業評価を高める要因になっていることを明ら かにしている。しかし、ここでは教師がどのよう な評価基準、すなわち個人内評価、相対評価、絶 対評価によって、フィードバックの情報を伝達し ているかについては検討されていなかった。

個々の子どもの学習意欲や学習行動を促進させ るためには、体育教師はどのような評価基準の情 報を子ども達に与えることが有効であろうか。滝 川・長谷川 (1996) は体育授業における個人内評価 が子ども達の動機づけに及ぼす影響について小学 校 6 年生 4 学級のバスケットボール単元 (10時間) を詨象にした介入実験研究を行った。実験授業の 教師はできるだけ、例えば「○○が前よりよく なっている」などの個人内評価による言葉かけを 多用し、それ以外の対照授業の教師は通常どおり に指導するように求めた。っその結果、個人内評価 を強調した授業では子どもの課題目標志向を高 め、それが満足感や学習行動にプラスの影響を及 ぼすことが示唆された。ただし、この研究では、 教師の言葉かけが個人の目標志向性に与える長期 的な影響や、Ames (1992)が提唱する授業の䨌囲 気知覚への影響については検討しておらず、ま た、授業の中で実際に教師が発した言葉かけの内 容は分析されなかった。

それに続く下田・長谷川ほか(1998)は、1学期 間における小学校 6 年生 3 学級の体育授業を対象 に介入実験授業によって検討した。ここでは介入 教師 1 名と対照教師 2 名が実験に参加し、教師の 発話はMDで録音し分析された。介入授業の子ど も達は肯定的な内容で、かつ個人の進歩に関する 言葉かけを認知しやすく、それによって満足感や 課題目標志向、マスタリ一雲囲気知覚が向上する という結果が得られた。

これらの研究では、動機づけや学習行動に対する 個人の進歩を強調する教師の言葉かけの有効性が示 唆された。しかし、いずれの研究も6年生を対象と しており、それ以外の学年の児童に同様の教授方略 が有効であるかを検討する必要がある。また、複数 教師による比較授業ではなく、介入教師個人が介入 前後でどのような教授行動の変化を示すかを明確に することは、教師研修プログラムへの適用可能性を 検討する観点からも重要である。 
そこで、本研究では、小学校中学年に属する4 年生担任の1教師を対象に、複数単元を継続的に 調査することで、評価構造を操作する単元前後で の児童の動機づけ変数の変化を検証することを目 的とした。具体的には、個人内評価により個人の 進歩を強調する言葉かけを教授方略として適用し た 1 介入単元と介入単元前に実施された対照単元 とを比較し、児童の動機づけにどのような効果を 及ぼすかを検討した。

\section{1. 研究方法 \\ 1. 対象授業}

茨城県 $S$ 市立 $\mathrm{T}$ 小学校の 4 年生 1 学級を対象学級 とした。児童は男子10名、女子11名の計 21 名で あった。そのうち、体育授業に参加しなかった児 童 2名（男子1名、女子 1名）については分析か ら除いた。担任教師は同校の体育主任を務める保 健体育科免許状を所有する教職経験 11 年の男性教 諭であった。

研究対象とした授業は、2002年1学期6月 16日 〜7月9日に実施されたマット運動（7時間）と同 年 2 学期 11 月6日〜12月11日に実施されたポート ボール (9 時間) である。本研究では、1学期の マット運動は介入を加えない対照単元とし、2学 期のポートボールを介入単元として設定した(注2)。 種目選択については2単元以上を対象とすること を依頼した結果、カリキュラムの都合で上述の設 定となった。

学校長と担任教師には研究の主旨ならびに方法 を事前に十分説明したうえで研究参加の許可を得 た。また、対象の生徒に対する調査と授業参観に ついては、担任教師を通じて生徒の保護者に説明 された。

\section{2. 介入単元の操作条件}

1 学期に実施されたマット運動においては特別 な介入は実施しなかった。2 学期に実施された ポートボールにおいては、教師の言葉かけに対し て以下の操作条件を設定し、体育授業の評価構造 を変化させる介入を実施した。

介入単元において担任教師は、個人内評価に基 づいた評価により、個人の進歩を強調したフィー ドバックを数多く行う。具体的には、「パスが前
よりもうまくなってきたね。」「前よりシュートが 成功するようになったね。」「今までで最高の記録 だね」などである。また、览童に教師の言葉を伝え る際には、下田ほか（1998）や高橋ほか（1996）の 方策を採用し、個人またはチームに対して「今の攻 撃はどうだった?」などの発問を用いて、それに応 答しながらフィードバックを与えるように依頼し た。このような発問を投げかけることで、教師は照 童が意識する課題を確認でき、それに応じたフィー ドバックが可能となるからである。

対照単元においては操作についての条件は与之 ず、普段通りの授業実践を行うよう依頼した。

\section{3. 授業中の教師の言葉かけの録音と分析}

教師にMD録音機を携行させ、その授業での教 師の発話を記録した。その後、記録をおこし出現 した教師の言葉かけからフィードバックをカテゴ リーに分類して、対照単元と介入単元の評価構造 を比較した。

発話記録の分析は、まず、高橋ほか (1992) の 教師行動のカテゴリーに従い、指示、フィード バック、発問、励まし、その他の5つに分類した。 さらに、フィードバックについては、深見・高橋 ほか（1996）の分類カテゴリーである評価内容、 評価観点、具体性、対象の 4 次元に「評価基準」 を加えた 5 次元で分類した。評価内容の次元は肯 定的（「うまいよ」「ナイスシュート」など肯定的 に評価したほめ言葉)、矯正的（「低くドリブルし たほうがいいよ」など)、否定的（「そんな形じゃ 駄目だろ」など）に分かれる。評価観点の次元は 技能的（児童の技能パフォーマンスに対するも の)、認知的（「いい考えだ」「いところに気づい た」などの児童の認知や思考に対するもの)、行動 的（「早く集まれてすばらしい」「大きな声でいい よ」など児童の一般的な行動に対するもの）に分 かれる。具体性の次元は具体的な情報を伴うかど うかで一般的と具体的に分かれる。対象の次元は そのフィードバックが向けられた対象の規模に よって個人、グループ、クラスに分かれる。

本研究で加えた評価基準の次元は、個人内基準 (「シュート前より良くなったね」「この技できる ようになったね」など個人の進歩を判定基準とす るもの)、相対基準（「○○さんよりうまいぞ」 
「○○ームの勝ち」など他者との優劣を評価の 判定基準とするもの)、その他（単に「OK」「い いよ」「だめ」など明確な判定基準が表明されて いないもの）の3つに分かれる。なお、到達度評 価などの絶対基準によるフィードバックは本研究 の対象授業では出現しなかった。

\section{4. 児童による教師及び友達からの言葉かけの認 知と形成的授業評価}

教授方略の操作が適切に実施されているか、授 業構造がどのようになっているかを確認するため に、長谷川ほか（1995）の作成した形成的授業評 価 (9項目)を各授業後に実施した。同時に、児童 には、その授業中に教師及び友達からかけられた 言葉の有無、及び印象に残った言葉かけについて 記述させた。また、それらの言葉かけが「役に 立ったか」について、「はい」、「どちらでもな い」、「いえ」の3段階で評定させる。

\section{5. 動機づけ変数の測定方法}

体育授業の評価構造を規定する要因としての教 師の言葉かけを操作することにより、児童の目標 志向性と雲囲気知覚の動機づけ变数や、それらに 関連する満足感、愛好的態度、能力知覚など情意 変数が適応的に変化するかを検討するために以下 の質問項目からなる質問紙調査票を構成した。目 標志向性と満足感の各尺度は Duda ほか（1992） を参照して滝川・長谷川（1996）、長谷川ほか （1999）が作成したものを使用した。雾囲気知覚 の尺度は、長谷川・下田ほか (1998，1999）が Biddleほか（1995）を邦訳し修正したもの使用し た。それぞれの尺度は以下の通りである。

(1)目標志向性尺度：個人変数としての目標志向 を測定するもので 12 項目からなり、課題目標と 自我目標の 2 つ位尺度で構成されている。 「体育の授業でどのようなときにうれしくなりま すか」という問いかけに対して、それぞれ「たい へんうれしい」から「まったくうれしくない」の 4段階で評定させる。課題目標の質問項目には、

「前にできなかった技ができるようになったと き」などの 6 項目 $(\alpha=.85)$ 、自我目標の質問項 目には、「他の人より成績が良かったとき」など の 6 項目（ $\alpha=.80 ）$ である。
(2)雲囲気知覚尺度：状況変数としての目標志向 を測定するもので26項目からなり、「体育の授業 中の雲囲気は・・・である」という問いかけで回 答を求める。それぞれ「よくあてはまる」から 「まったくあてはまらない」の4段階で評定させ る。䨌囲気知覚尺度については 2 カテゴリーの 5 下位尺度から構成されており、本研究のデータで

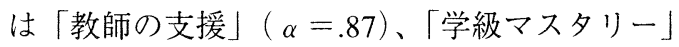
$(\alpha=.89)$ 、「選択の知覚」 $(\alpha=.20)$ 、「失敗・不 安」 $(\alpha=.81) 、 「$ 学級パフォーマンス」 $(\alpha=$ .58）の信頼度係数が得られた。本研究では「選択 の知覚」は信頼度係数が低かったためこれらの項 目は採用しなかった。本研究では、以後「教師の 支援」「学級マスタリー」をまとめて「マス夕 リ一䨌囲気知覚」 $(\alpha=.90) 、\lceil$ 失敗・不安」と 「学級パフォーマンス」をまとめて「パフォーマ ンス䨌囲気知覚」 $(\alpha=.76)$ とする。

(3)満足感尺度：「体育授業では、あなたはどの ように感じることがありますか」という問いかけ で、7項目について「いつも感じる」から「まっ たく感じない」の4段階で評定させる。例えば

「体育の授業はいつも短いと感じる」「体育の授 業は早く終わらないかなあと思う」(反転項目) などである（ $\alpha=.88 ）$ 。

(4)愛好的態度尺度：「体育が好きですか」の 1 項目について、「たいへん好き」から「たいへん きらい」の 4 段階で評定させる。

(5)能力知覚尺度：「体育が得意ですか」の 1 項 目について、「たいへん得意」から「まったく得 意でない」の 4 段階で評定させる。

\section{6. データの収集と分析の方法}

$\mathrm{MD}$ 録音機による教師の発話デー夕は対照単元 の4授業（第1,2,4,7時の授業）について、また、 介入授業については第 2 時を除く 8 授業について 得ることができた。それ以外の授業では機器操作 の不備によって収録することができなかった。カ テゴリーの分類は著者ともう 1 名で実施し、異な る分類をした場合には協議の上、決定した。形成 的授業評価及び言葉かけの調査は、対照単元と介 入単元のすべての授業で授業終了直後に担任教師 によって実施した。また、動機づけ変数の測定 は、対照単元中に基準データとして1回、介入単 
元の事前と事後にそれぞれ 1 回の計 3 回行った。

これらのデータの統計処理についてはSPSS統計 パッケージ第11版によって行った。

\section{III. 結果と考察}

\section{1. 対照単元と介入単元の授業構造の比較}

介入単元における操作条件が適切に実施されて いたかどうかについては、(1)教師の発話記録、(2) 児童が認知した教師の言葉かけの数及び認知内 容、(3)児童が認知した友達の言葉かけの数及び認 知内容について対照単元と介入単元で変化したか を比較検討した。

\section{(1) 教師の発話記録の分析}

授業中に録音された発話記録からフィードバッ クの評価内容の次元（肯定的、矯正的、否定的） と評価基準の次元（個人内、相対、その他）を分 類した結果は、表1に示してある。

1 授業あたりの平均フィードバック回数につい ては、対照単元のマット運動が55.4回で介入単元 のポートボールが57.3回と統計的に有意な差は認 められなかった。しかし、 $\chi^{2}$ 検定の結果、評価 内容の次元をみると、対照単元では肯定的の割合 が38.5\%に対して矯正的は $61.1 \%$ ああったのが、 介入単元ではそれぞれ $60.9 \% 、 38.0 \%$ となった $\left(\chi^{2}(2)=32.44, \mathrm{p}<.001\right)$ 。評価基準に関しては個 人内評価の割合が対照単元でわずかに $3.6 \%(1$ 授 業平均2.0回）であったのに対して、介入単元では $22.7 \%$ (1授業平均 13.0 回）と大きく変化していた $\left(\chi^{2}(1)=39.43, \mathrm{p}<.001\right)$ 。

小学校6年生を対象にした先行研究（下田・長 谷川ほか, 1998）の介入教師による陸上と器械運 動での発話記録では、内容の次元は肯定的 64.4 \%、矯正的 $34.7 \%$ 、また評価基準の次元は個人内 $30.1 \%$ 、その他 $68.5 \%$ であった。一方、操作を加 えなかった対照教師 2 名はそれぞれ肯定的 51.4 $\%$ 、矯正的 $48.0 \%$ 、また個人内 $16.2 \%$ 、その他 $81.8 \%$ と、肯定的 $44.8 \%$ 、矯正的 $51.3 \%$ 、また個 人内 $11.0 \%$ 、その他 $89.0 \%$ であった。このように 本研究で得られた対照単元と介入単元の各分類力 テゴリーの数值は、先行研究の数值とほぼ同一の 水準であった。

(2)児童が認知した教師からの言葉かけの認知数と 記述内容
表2は、各単元の各授業における教師からの言 葉かけを認知したと回答した生徒の数とその記述 内容の内訳を示している。

単元における言葉かけの認知・非認知の分布は 有意に異なっていた $\left(\chi^{2}(1)=20.89, \mathrm{p}<.001\right)$ 。教 師からの言葉かけを認知したと回答した児童の割 合は、対照単元では $28.1 \%$ (1 授業平均 4.9 人) で あったのに対して介入単元では $56.3 \%$ (1授業平均 9.9 人）と大きく増加した。特に介入単元の前半 4 授業では $37.7 \%$ \%゙ったのが、後半 5 授業では $62.1 \%$ と大きく向上した。これらの数值は下田・ 長谷川ほか（1998）とほぼ同水準であうた。介入 教師が行った陸上運動、器械運動、水泳の 21 授業 での教師の言葉かけを小学校 6 年生（22名）の $56.2 \%$ (1授業平均 12.4 人) が認知していたのに対 して、操作を加えなかった対照教師2名の授業で はそれぞれ29名のうち $29.7 \%$ (8.6人,15授業)、19 名のうち $25.6 \%$ （4.9人,18授業）であった。览童の 記述内容は、教師の発話記録と同じ基準で、評価 内容と評価基準の次元でカテゴリー分類した。評 価基準については個人内評価とその他の割合が単 元で有意に異なり $\left(\chi^{2}(1)=9.30, \mathrm{p}<.01\right)$ 、個人内 評価が対照単元で $17.6 \%$ であったのが、介入単元 では $47.7 \%$ と増加していた。加えて認知された個 人内評価の内容は多くが肯定的な内容であった。 統計的に有意な偏りではなかったが、肯定的は対 照単元では $35.3 \%$ 介入入単元では $54.5 \%$ となっ た。下田・長谷川ほか（1998）の介入教師での記 述内容は、評価内容に関しては肯定的 $47.0 \%$ 、矯 正的 $39.2 \%$ 、その他 $13.8 \%$ で、個人内の評価基準 は19.4\%であった。一方、対照教師 2名は肯定的 (それぞれ $21.8 \%$ と $14.7 \%$ ) よりも矯正的（それ ぞれ $60.0 \%$ と $73.4 \%$ ）の内容の割合が高く、また 個人内はわずかに $3.6 \%$ と $1.4 \%$ であった。した がって介入群において児童による記述内容は、肯 定的な個人内評価の内容が多いという傾向は一致 していた。

(3)児童が認知した友達からの言葉かけの認知数と 記述内容

また表3は各単元の各授業における友達からの 言葉かけの認知数とその記述内容の内訳を示して いる。

ここでも単元を比較すると言葉かけの認知・非 
長谷川：小学校体育授業における「個人の進歩」を強調した教師の言葉かけが児童の動機づけに及ぼす効果

表 1 発話記録における教師の言葉かけの回数と内容

\begin{tabular}{|c|c|c|c|c|c|c|c|c|}
\hline \multirow{2}{*}{ 単元名 } & \multirow{2}{*}{ 授業時 } & \multirow{2}{*}{ フイドバック } & \multicolumn{3}{|c|}{ 評価内容の次元 } & \multicolumn{3}{|c|}{ 評価基準の次元 } \\
\hline & & & 肯定的 & 矯正的 & 否定的 & 個人内 & 相対 & その他 \\
\hline \multirow[t]{4}{*}{ マット運動 } & 1 & 56 & 24 & 32 & 0 & 4 & 0 & 52 \\
\hline & 2 & 59 & 16 & 42 & 1 & 1 & 0 & 58 \\
\hline & 4 & 47 & 18 & 29 & 0 & 2 & 0 & 45 \\
\hline & 6 & 59 & 27 & 32 & 0 & 1 & 0 & 58 \\
\hline \multirow[t]{8}{*}{ ポートボール } & 1 & 50 & 21 & 28 & 1 & 2 & 1 & 47 \\
\hline & 3 & 54 & 31 & 23 & 0 & 15 & 0 & 39 \\
\hline & 4 & 48 & 26 & 21 & 1 & 9 & 0 & 39 \\
\hline & 5 & 67 & 50 & 16 & 1 & 11 & 0 & 56 \\
\hline & 6 & 66 & 42 & 23 & 1 & 15 & 0 & 51 \\
\hline & 7 & 59 & 34 & 25 & 0 & 14 & 0 & 45 \\
\hline & 8 & 48 & 31 & 17 & 0 & 15 & 0 & 33 \\
\hline & 9 & 66 & 44 & 21 & 1 & 23 & 0 & 43 \\
\hline \multirow[t]{2}{*}{ 対照単元 } & 割合 & $100.0 \%$ & $38.5 \%$ & $61.0 \%$ & $0.5 \%$ & $3.6 \%$ & $0.0 \%$ & $96.4 \%$ \\
\hline & 平均 (回) & 55.3 & 21.3 & 33.8 & 0.3 & 2.0 & 0.0 & 53.3 \\
\hline \multirow[t]{2}{*}{ 介入単元 } & 割合 & $100.0 \%$ & $60.9 \%$ & $38.0 \%$ & $1.1 \%$ & $22.7 \%$ & $0.2 \%$ & $77.1 \%$ \\
\hline & 平均 (回) & 57.3 & 34.9 & 21.8 & 0.6 & 13.0 & 0.1 & 44.2 \\
\hline
\end{tabular}

表 2 児童による教師からの言葉かけの認知数とその記述内容

\begin{tabular}{|c|c|c|c|c|c|c|c|c|c|c|}
\hline \multirow{2}{*}{ 単元名 } & \multirow{2}{*}{ 授業時 } & \multicolumn{2}{|c|}{ 言葉かけけの認知 } & \multicolumn{4}{|c|}{ 評価内容の次元 } & \multicolumn{3}{|c|}{ 評価基準の次元 } \\
\hline & & 有 & $\begin{array}{l}\text { 無 } \\
\end{array}$ & 肯定的 & 矯正的 & 否定的 & 云の他 & 個人内 & 相対 & その他 \\
\hline \multirow[t]{7}{*}{ マット運動 } & $* 1$ & 6 & 12 & 2 & 1 & 0 & 3 & 0 & 0 & 6 \\
\hline & $* 2$ & 6 & 11 & 2 & 2 & 0 & 2 & 1 & 0 & 5 \\
\hline & 3 & 6 & 10 & 2 & 3 & 0 & 1 & 1 & 0 & 5 \\
\hline & $* 4$ & 5 & 12 & 2 & 1 & 0 & 2 & 1 & 0 & 4 \\
\hline & 5 & 6 & 13 & 3 & 2 & 0 & 1 & 2 & 0 & 4 \\
\hline & 6 & 3 & 14 & 1 & 1 & 0 & 1 & 1 & 0 & 2 \\
\hline & $* 7$ & 2 & 15 & 0 & 1 & 0 & 1 & 0 & 0 & 2 \\
\hline \multirow[t]{9}{*}{ ポートボール } & $* 1$ & 6 & 13 & 2 & 1 & 0 & 3 & 2 & 0 & 4 \\
\hline & 2 & 6 & 13 & 3 & 2 & 0 & 1 & 3 & 0 & 3 \\
\hline & $* 3$ & 9 & 10 & 4 & 2 & 0 & 3 & 5 & 0 & 4 \\
\hline & $* 4$ & 9 & 9 & 7 & 1 & 0 & 1 & 4 & 0 & 5 \\
\hline & $* 5$ & 13 & 4 & 7 & 4 & 0 & 2 & 7 & 0 & 6 \\
\hline & $* 6$ & 13 & 5 & 9 & 2 & 0 & 2 & 7 & 0 & 6 \\
\hline & $* 7$ & 11 & 5 & 5 & 3 & 0 & 3 & 5 & 0 & 6 \\
\hline & $* 8$ & 9 & 8 & 6 & 2 & 0 & 1 & 6 & 0 & 3 \\
\hline & $* 9$ & 13 & 2 & 5 & 5 & 0 & 3 & 3 & 0 & 10 \\
\hline \multirow[t]{2}{*}{ 対象単元 } & 割合 & $28.1 \%$ & $71.9 \%$ & $35.2 \%$ & $32.4 \%$ & $0.0 \%$ & $32.4 \%$ & $17.6 \%$ & $0.0 \%$ & $82.4 \%$ \\
\hline & 平均 (人) & 4.9 & 12.4 & 1.7 & 1.6 & 0.0 & 1.6 & 0.9 & 0.0 & 4.0 \\
\hline \multirow[t]{2}{*}{ 介入単元 } & 割合 & $56.3 \%$ & $43.7 \%$ & $53.9 \%$ & $24.7 \%$ & $0.0 \%$ & $21.3 \%$ & $47.2 \%$ & $0.0 \%$ & $52.8 \%$ \\
\hline & 平均 (人) & 9.9 & 7.7 & 5.3 & 2.4 & 0.0 & 2.1 & 4.7 & 0.0 & 5.2 \\
\hline
\end{tabular}

番号に*のついた授業は、MD録音機により発話を記録した授業を示す。

表 3 児童による友達からの言葉かけの認知数とその記述内容

\begin{tabular}{|c|c|c|c|c|c|c|c|c|c|c|}
\hline \multirow{2}{*}{ 単元名 } & \multirow{2}{*}{ 授業時 } & \multicolumn{2}{|c|}{ 言葉かけの認知 } & \multicolumn{4}{|c|}{ 評価内容の次元 } & \multicolumn{3}{|c|}{ 評価基準の次元 } \\
\hline & & 有 & 無 & 肯定的 & 矯正的 & 否定的 & その他 & 個人内 & 相詨 & その他 \\
\hline \multirow[t]{7}{*}{ マット運動 } & $* 1$ & 6 & 12 & 0 & 0 & 0 & 6 & 0 & 0 & 6 \\
\hline & $* 2$ & 6 & 11 & 2 & 0 & 0 & 4 & 1 & 0 & 5 \\
\hline & 3 & 8 & 8 & 2 & 1 & 0 & 5 & 2 & 0 & 6 \\
\hline & $* 4$ & 5 & 12 & 1 & 0 & 0 & 4 & 0 & 0 & 5 \\
\hline & 5 & 7 & 12 & 1 & 2 & 0 & 4 & 1 & 0 & 6 \\
\hline & 6 & 2 & 15 & 0 & 0 & 0 & 2 & 0 & 0 & 2 \\
\hline & $* 7$ & 1 & 16 & 0 & 0 & 0 & 1 & 0 & 0 & 1 \\
\hline \multirow[t]{9}{*}{ ポートボール } & $* 1$ & 8 & 11 & 1 & 3 & 0 & 4 & 1 & 0 & 7 \\
\hline & 2 & 6 & 13 & 1 & 2 & 0 & 3 & 0 & 0 & 6 \\
\hline & $* 3$ & 6 & 13 & 2 & 1 & 0 & 3 & 2 & 0 & 4 \\
\hline & $* 4$ & 5 & 13 & 3 & 1 & 0 & 1 & 0 & 0 & 5 \\
\hline & *5 & 11 & 6 & 4 & 2 & 0 & 5 & 1 & 0 & 10 \\
\hline & $* 6$ & 10 & 8 & 3 & 1 & 0 & 5 & 2 & 0 & 8 \\
\hline & $* 7$ & 12 & 4 & 4 & 1 & 2 & 5 & 1 & 0 & 11 \\
\hline & $* 8$ & 6 & 11 & 1 & 1 & 1 & 3 & 0 & 0 & 6 \\
\hline & $* 9$ & 11 & 4 & 1 & 1 & 2 & 7 & 0 & 0 & 11 \\
\hline \multirow[t]{2}{*}{ 対象単元 } & 割合 & $28.9 \%$ & $71.1 \%$ & $17.1 \%$ & $8.6 \%$ & $0.0 \%$ & $74.3 \%$ & $11.4 \%$ & $0.0 \%$ & $88.6 \%$ \\
\hline & 平均 (人) & 5.0 & 12.3 & 0.9 & 0.4 & 0.0 & 3.7 & 0.6 & 0.0 & 4.4 \\
\hline \multirow{2}{*}{ 介入単元 } & 割合 & $47.5 \%$ & $52.5 \%$ & $27.0 \%$ & $17.6 \%$ & $6.8 \%$ & $48.6 \%$ & $9.3 \%$ & $0.0 \%$ & $90.7 \%$ \\
\hline & 平均 (人) & 8.3 & 9.2 & 2.2 & 1.4 & 0.6 & 4.0 & 0.8 & 0.0 & 7.6 \\
\hline
\end{tabular}

番号に*のついた授業は、MD録音機により発話を記録した授業を示す. 
表 4 単元前後での児童の動機づけ変数得点の変化

\begin{tabular}{|c|c|c|c|c|}
\hline & 対照単元(1) & 介入単元前(2) & 介入単元後(3) & 対応のある $\mathrm{t}$ 検定 $(\mathrm{t}$ 值) \\
\hline 課題目標志向性 & $3.04(0.52)$ & $3.00(0.46)$ & $3.52(0.62)$ & (3) $3.07 * *$, (2)<(3) $3.52 * *$ \\
\hline 自我目標志向性 & $3.09(0.56)$ & $3.11(0.51)$ & $2.57(0.97)$ & (1) $>$ (3) $2.21 *$ \\
\hline マスタリー雰囲気知覚 & $3.34(0.68)$ & $3.37(0.42)$ & $3.60(0.40)$ & (3) $1.93 \dagger$ \\
\hline パフォーマンス雰囲気知覚 & $2.70(0.56)$ & $2.77(0.54)$ & $2.47(0.69)$ & $2.15 *$ \\
\hline 満足感 & $3.23(0.6$ & $3.30(0.4$ & $3.56(0.56)$ & (1) $<$ (3) $1.99 \dagger$, (2)< (3) $1.90 \dagger$ \\
\hline 愛好的態度 & $3.32(0.82)$ & $3.37(0.76)$ & $3.68(0.67)$ & (1) $<$ (3) $1.79 \dagger$ \\
\hline 能力知覚 & $3.00(0.67)$ & $2.79(0.63)$ & $3.16(0.90)$ & (1) $<$ (2) $2.19 *$, (2) $<$ (3) $1.93 \dagger$ \\
\hline
\end{tabular}

$\dagger \mathrm{p}<.10, * \mathrm{p}<.05, * * \mathrm{p}<.01 . \mathrm{N}=19$.

認知の分布は有意に異なった $\left(\chi^{2}(1)=9.97, \mathrm{p}<\right.$ .01)。友達からの言葉かけの認知した児童の割合 は、対照単元ではでは $28.9 \%$ (1 授業平均 5.0 人) であったのが、介入単元では $56.3 \%$ （1授業平均 8.3人）と増加していた。また、友達からの言葉か けの内容については有意な傾向にあり、介入単元 で肯定的と矯正的がそれぞれ増加し、その他が減 少していた $\left(\chi^{2}(2)=4.80, \mathrm{p}<.10\right)$ 。評価の基準に 関しては有意な差は認められなかった。

小学校 6 年生 4 学級でのバスケットボール単元 を対象にした長谷川・滝川ほか（1997）では、肯 定的な個人内評価を強調した介入クラス（38名） の教師からの言葉かけの認知率が $32.2 \%(12.2$ 人）と、同規模の3つの対照クラス (8.4-28.7\%) より高く、同様に友達からの言葉かけの認知率が $33.2 \%$ (12.6人) で対照クラス (15.7-24.2\%) より も高かった。本研究の介入は 4 年生のポートボー ル単元であったが、教師による個人の進歩を強調 した教師の言葉かけは、児童相互の言葉かけを促 進するという効果があることを示唆した。

以上の結果により、介入単元では個人の進歩を 強調する言葉かけが数多く用いられたており、介 入が適切に実施されたことが確認された。介入単 元で教師は、意図的に個人内評価基準による肯定 的な言葉かけを多用して児童との積極的な相互作 用を実行していた。それに伴って介入単元におけ る児童による教師からの言葉かけの認知率は対照 単元よりも大きく向上していた。

\section{2. 介入単元前後の児童の動機づけ变数及び形成 的授業評価得点の変化}

個人内評価によって個人の進歩を強調する言葉
かけを多く行うことで、児童の動機づけがどのよ うに変化するか、また2つの単元における形成的 授業評価得点を比較検討した。

表4 からわかるように、児童の課題志向性得点 は、対照単元、介入単元前に比べて介入単元後で有 意に向上し、反対に自我志向性得点は介入単元後で 有意に低下していた。マスタリー雾囲気知覚得点 は、介入単元前より介入単元後が高くなり、反対に パフォーマンス雲囲気知覚得点は介入後に低下する 傾向を示した。また、介入単元後に体育授業におけ る満足感と能力知覚の得点が有意に向上する傾向が みられた。体育授業に対する愛好的態度得点につい ては介入単元前後には有意差はみられなかったが、 対照単元よりも有意に高かった。

表5のように各児童の単元毎の形成的授業評価 の平均得点については、成果次元で有意な差が見 られ、対照単元に比べて介入単元において高得点 であった。

以上から、介入単元において児童の動機づけ変 数は先行研究と同様の適応的な变容パターンを示 した（Ames, 1992, 長谷川・滝川ほか, 1997，下 田・長谷川ほか, 1998)。加えて形成的授業評価も 成果次元のみではあるが望ましい差が認められた。

\section{表 5 児童の形成的授業評価得点の比較}

\begin{tabular}{llll}
\hline & 対照単元 & 介入単元 & $\mathrm{t}$ 值 $^{\mathrm{a}}$ \\
\hline 総合 & $2.60(0.14)$ & $2.72(0.35)$ & \\
成果 & $2.24(0.22)$ & $2.61(0.41)$ & $3.14 * *$ \\
意欲・関心 & $2.84(0.19)$ & $2.84(0.33)$ & \\
学び方 & $2.76(0.20)$ & $2.76(0.39)$ & \\
協力 & $2.74(0.23)$ & $2.73(0.35)$ & \\
\hline
\end{tabular}

** $\mathrm{p}<.01 . \mathrm{N}=19$ $^{\mathrm{a}}$ 対応のあるt検定によるt值. 


\section{3. 言葉かけの認知数、動機づけ変数及び形成的 授業評価との関係}

(1) 言葉かけの認知数と動機づけ変数との関係

まず、児童が各単元で認知した言葉かけの数と 3つの時点で測定した動機づけ変数得点との相関 係数を算出した。

表6に示すように、対照単元における言葉かけ の認知数は、動機づけ変数との間に有意な相関関 係が概ねみられなかった。それに対して介入単元 における言葉かけの認知数は、3 時点のうち介入 単元後に測定した動機づけ变数との間に有意な相 関関係を示した。特に、教師からの言葉かけは、 介入単元後の課題志向性、マスタリー雲囲気知 覚、満足度、愛好的態度、能力知覚度との間に有 意な正の相関関係が認められた。このうちマス夕 リ一雲囲気知覚に対しては.74の高い相関值がみら れた。また、パフォーマンス雲囲気知覚との間に は負の相関関倸 (-.50) が認められた。

この結果は、個人内評価による進歩を強調した 教師の言葉かけを多く認知した児童ほど、その動 機づけ状態は適応的なパターンを示すという先行 研究の結果を支持した(下田・長谷川ほか，1998）。

\section{(2) 言葉の認知数と形成的授業評価との関係}

次に、児童の各単元における言葉かけの認知数 と各単元の形成的授業評価の平均得点との相関係 数を算出した。表6からは対照単元での言葉かけ の認知数は、対照単元の成果次元の形成的授業評 価との間だけに.43〜.50程度の有意な相関関係が みられた。一方、介入単元での言葉かけの認知数 は、形成的授業評価の総合と4次元の全ての変数 との間に.50〜79までのやや強い有意な正の相関関 係を示した。ここからは、介入単元で教師が発し た言葉かけは、対照単元での言葉かけに比べて、 児童の動機づけ状態だけでなく、児童の学習行動 や学習成果に対してもより有効に機能していたこ とが推察された。

\section{(3) 動機づけ変数と形成的授業評価との関係}

表7から、動機づけ変数と形成的授業評価との 関係についてみると、対照単元の形成的授業評価 得点と 3 時点での動機づけ変数との間には明確な 相関関係が認められなかった。しかし、介入単元 後の動機づけ変数と介入単元での形成的授業評価 得点との間では、明確な相関関係パターンが示さ れた。つまり、児童の学習行動や学習成果と、課

表 6 児童の言葉かけの認知数と動機づけ変数及び形成的授業評価との相関関係

\begin{tabular}{|c|c|c|c|c|c|c|c|c|c|c|c|}
\hline & & \multicolumn{2}{|c|}{ 対照単元での言葉かけ } & \multicolumn{2}{|c|}{ 介入単元での言葉かけ } & & & \multicolumn{2}{|c|}{ 対照単元での言葉かけ } & \multicolumn{2}{|c|}{ 介入単元での言葉かけ } \\
\hline & & 教師力心 & 友達加 & 教師から & 友達から & & & 教師から & 友達加 & 教師から & 友達か心 \\
\hline 動機づけ変数 & & & & & & 形成的授業評任 & & & & & \\
\hline 課題志向性 & $\begin{array}{l}\text { 対照单元 } \\
\text { 介入単元前 } \\
\text { 介入単元後 }\end{array}$ & $\begin{array}{r}.14 \\
.19 \\
-.30\end{array}$ & $\begin{array}{r}.07 \\
.02 \\
-.42\end{array}$ & $\begin{array}{l}-.05 \\
-.04 \\
.46 *\end{array}$ & $\begin{array}{l}.02 \\
.10 \\
.29\end{array}$ & 総合評価 & $\begin{array}{l}\text { 対象单元 } \\
\text { 介入単元 }\end{array}$ & $\begin{array}{l}.27 \\
.07\end{array}$ & $\begin{array}{r}.40 \\
-.01\end{array}$ & $\begin{array}{l}.03 \\
.74 * *\end{array}$ & $\begin{array}{l}-.08 \\
.65 * *\end{array}$ \\
\hline 自我志向性 & $\begin{array}{l}\text { 対照単元 } \\
\text { 介入単元前 } \\
\text { 介入単元後 }\end{array}$ & $\begin{array}{l}.18 \\
.30 \\
.29\end{array}$ & $\begin{array}{l}.15 \\
.20 \\
.48 *\end{array}$ & $\begin{array}{r}.12 \\
.14 \\
-.43\end{array}$ & $\begin{array}{r}.31 \\
.31 \\
-.41\end{array}$ & 成果 & $\begin{array}{l}\text { 対象単元 } \\
\text { 介入単元 }\end{array}$ & $\begin{array}{r}.43 \\
-.02\end{array}$ & $\begin{array}{l}.46 * \\
-.06\end{array}$ & $\begin{array}{l}-.04 \\
.79 * *\end{array}$ & $\begin{array}{l}.11 \\
.66 * *\end{array}$ \\
\hline $\begin{array}{l}\text { マスタリ- } \\
\text { 雲讲気知覚 }\end{array}$ & $\begin{array}{l}\text { 対照単元 } \\
\text { 介入単元前 } \\
\text { 介入単元後 }\end{array}$ & $\begin{array}{r}.27 \\
.15 \\
-.02\end{array}$ & $\begin{array}{l}-.04 \\
-.13 \\
-.15\end{array}$ & $\begin{array}{l}-.03 \\
-.12 \\
.74 * *\end{array}$ & $\begin{array}{l}-.05 \\
-.18 \\
.50 *\end{array}$ & 意欲·関心 & $\begin{array}{l}\text { 対象単元 } \\
\text { 介入単元 }\end{array}$ & $\begin{array}{l}.28 \\
.00\end{array}$ & $\begin{array}{r}.41 \\
-.07\end{array}$ & $\begin{array}{l}.06 \\
.62 * *\end{array}$ & $\begin{array}{l}.10 \\
.50 *\end{array}$ \\
\hline $\begin{array}{l}\text { パフォーマソス } \\
\text { 霙囲気知覚 }\end{array}$ & $\begin{array}{l}\text { 対照単元 } \\
\text { 介入単元前 } \\
\text { 介入単元後 }\end{array}$ & $\begin{array}{l}.41 \\
.21 \\
.18\end{array}$ & $\begin{array}{l}.37 \\
.13 \\
.36\end{array}$ & $\begin{array}{r}.17 \\
.15 \\
-.50 *\end{array}$ & $\begin{array}{c}.22 \\
.10 \\
-.49 *\end{array}$ & 学び方 & $\begin{array}{l}\text { 対象単元 } \\
\text { 介入单元 }\end{array}$ & $\begin{array}{r}-.12 \\
.26\end{array}$ & $\begin{array}{l}.11 \\
.19\end{array}$ & $\begin{array}{l}.13 \\
.64 * *\end{array}$ & $\begin{array}{l}-.28 \\
.65 * *\end{array}$ \\
\hline 満足感 & $\begin{array}{l}\text { 対照単元 } \\
\text { 介入単元前 } \\
\text { 介入単元後 }\end{array}$ & $\begin{array}{r}.13 \\
-.03 \\
-.05\end{array}$ & $\begin{array}{l}-.03 \\
-.23 \\
-.17\end{array}$ & $\begin{array}{l}-.17 \\
-.20 \\
.53 *\end{array}$ & $\begin{array}{l}-.13 \\
-.23 \\
.53 *\end{array}$ & 協力 & $\begin{array}{l}\text { 対象単元 } \\
\text { 介入単元 }\end{array}$ & $\begin{array}{r}-.07 \\
.05\end{array}$ & $\begin{array}{l}-.03 \\
-.06\end{array}$ & 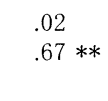 & $\begin{array}{l}-.27 \\
.55 * *\end{array}$ \\
\hline 愛好的態度 & $\begin{array}{l}\text { 対照単元 } \\
\text { 介入単元前 } \\
\text { 介入单元後 }\end{array}$ & $\begin{array}{r}.20 \\
.20 \\
-.27\end{array}$ & $\begin{array}{r}.23 \\
.29 \\
-.28\end{array}$ & $\begin{array}{r}.01 \\
-.05 \\
.48 *\end{array}$ & $\begin{array}{l}.06 \\
.02 \\
.39\end{array}$ & & & & & & \\
\hline 能力知覚 & $\begin{array}{l}\text { 対照単元 } \\
\text { 介入単元前 } \\
\text { 介入単元後 }\end{array}$ & $\begin{array}{r}.31 \\
.28 \\
-.01\end{array}$ & $\begin{array}{r}.24 \\
.21 \\
-.19\end{array}$ & $\begin{array}{l}-.30 \\
-.02 \\
.54 *\end{array}$ & $\begin{array}{r}-.23 \\
.05 \\
.40\end{array}$ & & & & & & \\
\hline
\end{tabular}

$* \mathrm{p}<.05, \quad * * \mathrm{p}<.01 . \mathrm{N}=19$. 
表 7 動機づけ変数と形成的授業評価との相関

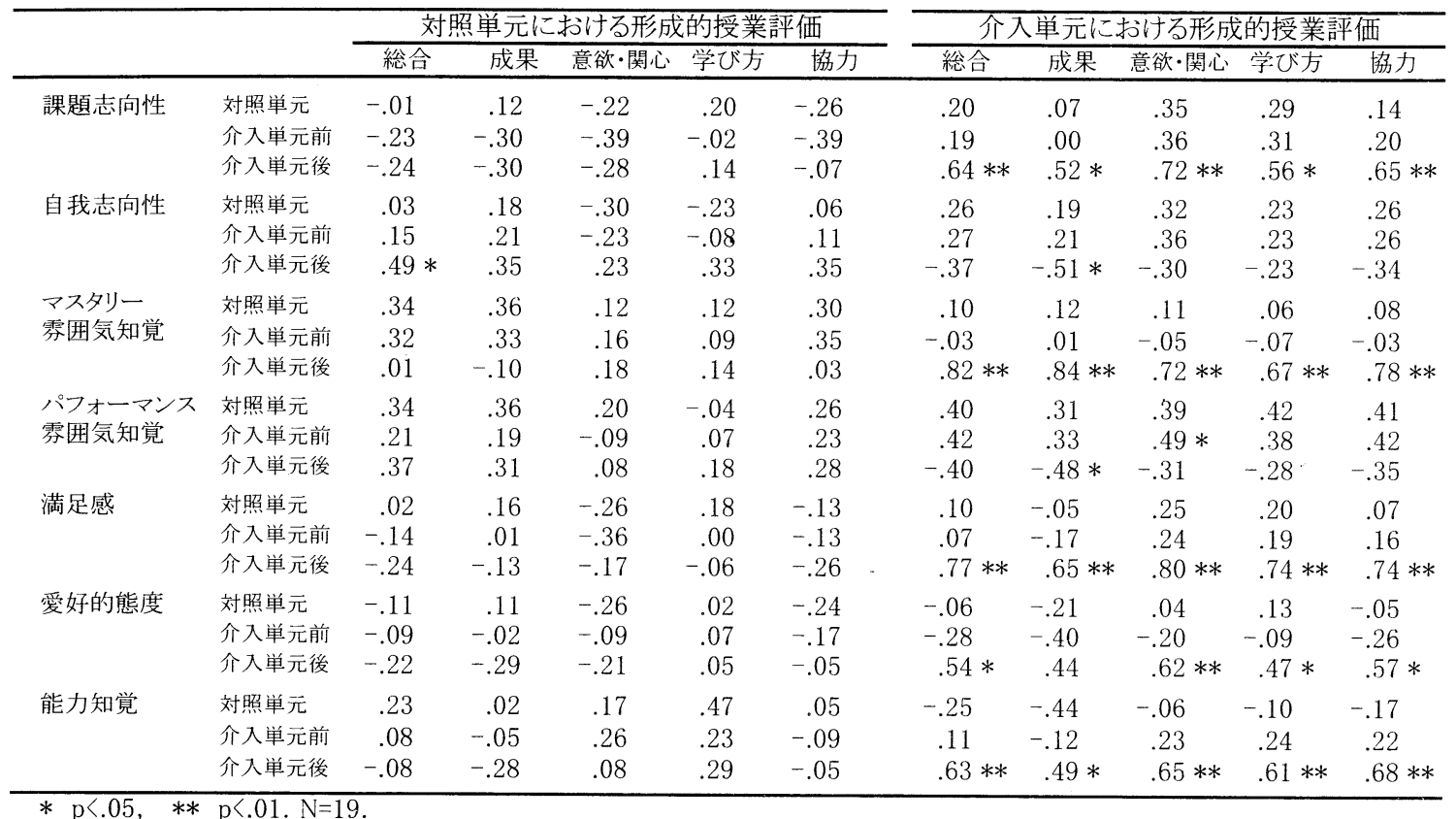

題志向性、マスタリー雾囲気知覚、満足度、愛好 度、能力知覚との間には正の相関関係が認めら れ、また、自我志向性とパフォーマンス䨌囲気知 覚との間には一定して負の相関関係がみられた。

以上より、介入単元における個人内評価によっ て進歩を強調する教師の言葉かけは、児童の動機 づけ変数ならびに形成的授業評価からみた学習行 動に適応的な影響を及ほしていることがわかっ た。

\section{4 . 児童のマスタリー雾囲気知覚を高める言葉か けの事例}

介入単元では、教師の言葉かけの認知数とマス タリー雲囲気知覚、パフォーマンス雾囲気知覚と の間に明確な相関関係が認められた。そこで、マ スタリー雲囲気知覚が向上し、また、パフォーマ ンス䨌囲気知覚が低下した览童が、実際の授業場 面で教師からどのような言葉をかけられたのかに ついて、児童の記述と逐語記録を照合すること で、雾囲気知覚を高めるための教師の有効な言葉 かけについて事例的に検討した。

まず、有効であると思われる教師の言葉かけの
抽出にあたり、次の4つの条件を設定した。(1)そ の言葉かけが役に立つという項目に「はい」と回 答されている。(2)当該览童の形成的授業評価が 2.80 以上。(3)介入単元前のマスタリ一雲囲気知 覚、パフォーマンス雾囲気知覚の得点分布から、 下高マスタリー・高パフォーマンス群、高マス夕 リー・低パフォーマンス群、低マスタリー・高パ フォーマンス群、低マスタリー・低パフォーマン ス群の 4 群に分け、ここで、介入単元後に他の3 群から高マスタリー・低パフォーマンス群に変化 した児童が記述したもの。なお、群分けに用いら れた中央值は、マスタリー雲囲気知覚が3.37、パ フォーマンス雲囲気知覚が2.77であった。(4)発話 が記録されており、記述が逐語記録と照合できる もの。

この条件を全て満たすものは8事例であった。 この 8 つの言葉かけの記述内容と、MD録音を起 こした発話記録の内容は表 8 に示す。

$8 つ の$ 言葉かけのいずれもが肯定的あるいは矯正 的なフィードバックで、览童の実際の運動観察に 基づいた解説をともなった明確な個人内基準によ る評価であった。また 6 事例（事例 $1,2,3,5,6,8$ ) 
表 8 介入単元（ポートボール）における教師からの言葉かけの事例

\begin{tabular}{|c|c|c|c|c|}
\hline & 単元・日時 & 名前 & 児童の記述と教師の発話記録 & カテゴリー \\
\hline \multirow[b]{2}{*}{1} & \multirow[b]{2}{*}{$\begin{array}{c}\text { 第1時 } \\
\text { 11月6日 }\end{array}$} & \multirow[b]{2}{*}{ Hさん } & 記述:「フワッとした山なりのボールにしな」 & 矯正 \\
\hline & & & $\begin{array}{l}\text { 逐語: (シュート練習をしている)/どうやったらうまくシュートできる? } \\
\text { /うん、シュートをする時にはそう、山なりのボールだよ。 } \\
/ \text { /そうそうそう、今みたいなボール。良くなったじやん！ }\end{array}$ & $\begin{array}{l}\text { 発問 } \\
\text { 矯正 } \\
\text { 肯定·個人内 }\end{array}$ \\
\hline \multirow[b]{2}{*}{2} & \multirow[b]{2}{*}{$\begin{array}{c}\text { 第3時 } \\
\text { 11月15日 }\end{array}$} & \multirow[b]{2}{*}{ Aさん } & 記述:「攻め側にどうやったらパスできるか考えたほうがいい」 & 矯正的 \\
\hline & & & $\begin{array}{l}\text { 逐語: (試合後に作戦を立てている)/やってみてどうだった?今の } \\
\text { 試合。/あの、あそこまで行くのにゴールからのパスをどう考えるか、 } \\
\text { 1本であそこにパスするのか、それとも2人余ってるんだから、そこ } \\
\text { をどう使うか考えたほうがいいよ。 } \\
\text { /(児童が意見を言った後に)ドリブルで抜くつてのも、良いね。 } \\
\text { /なかなか攻めの人にパスが繫がってないから、そこをどうするか } \\
\text { 考えたほうかよくなるね。 }\end{array}$ & $\begin{array}{l}\text { 発問 } \\
\text { 矯正 }\end{array}$ \\
\hline \multirow[b]{2}{*}{3} & \multirow[b]{2}{*}{$\begin{array}{c}\text { 第4時 } \\
11 \text { 月18日 }\end{array}$} & \multirow[b]{2}{*}{$\begin{array}{l}\text { Kさん } \\
\text { Yさん }\end{array}$} & 記述：「攻めが良くなつたね & 個人内·肯定 \\
\hline & & & $\begin{array}{l}\text { 逐語: (試合後に作戦を立てている)ここはどういら作戦？ } \\
\text { /(児童の意見の後に)あ、守りを背高い人にするのか。 } \\
\text { /攻めのほうは? } \\
\text { /(児童の意見の後に)うん、攻めはうまくなってるよね。シュートまで } \\
\text { いける時多くなったもんね。 }\end{array}$ & $\begin{array}{l}\text { 発問 } \\
\text { 応答 } \\
\text { 発問 } \\
\text { 個人内·肯定 }\end{array}$ \\
\hline \multirow[b]{2}{*}{4} & \multirow[b]{2}{*}{$\begin{array}{c}\text { 第5時 } \\
\text { 11月20日 }\end{array}$} & \multirow[b]{2}{*}{$\mathrm{H}<ん$} & 記述:「バウンドパスうまいね」 & 一般肯定 \\
\hline & & & $\begin{array}{l}\text { 逐語: (クラスの皆を集めて)/この前、良いプレーとして紹介した、 } \\
\text { バウンドするパス、バウンドさせてパスをする場面が何回か見られ } \\
\text { ました。大変良かったです。 } \\
\text { /Hくん使ってましたね。良かったです。うまくなってるぞ。 }\end{array}$ & 個人内·肯定 \\
\hline \multirow[b]{2}{*}{5} & \multirow[b]{2}{*}{$\begin{array}{c}\text { 第7時 } \\
\text { 11月29日 }\end{array}$} & \multirow[b]{2}{*}{ Aさん } & 記述:「守りから遠くにとばすために、横に来てもらつたほうがいい」 & 矯正 \\
\hline & & & $\begin{array}{l}\text { 逐語: (試合後に作戦を立てている) 先生1つ気づいたのが、Aさん } \\
\text { 一生眯命パスしたくて、遠くに投げようとしてるんだけど、Iんは } \\
\text { ジャンプ力もあるし、邪魔で投げづらいね。その時に・... } \\
\text { /(児童の意見後に)あ、良いこと気づいたね！ } \\
\text { /くんの後ろにいるとパスしにくいから横に行ってあげるの。Aさんも } \\
\text { 気づいたら横に来てって言ってあげる。 }\end{array}$ & $\begin{array}{l}\text { 肯定 } \\
\text { 矯正 }\end{array}$ \\
\hline \multirow[b]{2}{*}{6} & \multirow[b]{2}{*}{$\begin{array}{c}\text { 第8時 } \\
\text { 12月2日 }\end{array}$} & \multirow[b]{2}{*}{ Aさん } & 記述:「守りとてもうまくなってきたね」 & 個人内·肯定 \\
\hline & & & $\begin{array}{l}\text { 逐語: (試合後に作戦を立てている)守りはどうだった? } \\
\text { /(児童の意見後に) 先生見てての感想なんだけよ゙、Aさんは頑張っ } \\
\text { てこうパスカットしてるんだよな。凄くうまくなってて良い守りしてる。 } \\
\text { /だけど、そこからの攻めがここで止まっちゃうんだ。パスが慗がる } \\
\text { んだけど、シュートまでいかないんだよね。そこが残念。だから、A } \\
\text { さんが投げたくても誰もいないんだ。1人前に残ってるとか、そうい } \\
\text { う作戦を立てたほうがいいよ。 }\end{array}$ & $\begin{array}{l}\text { 個人内·肯定 } \\
\text { 矯正 }\end{array}$ \\
\hline \multirow[b]{2}{*}{7} & \multirow[b]{2}{*}{$\begin{array}{c}\text { 第9時 } \\
\text { 12月9日 }\end{array}$} & \multirow[b]{2}{*}{ Kさん } & 記述:「ロングシュート良くなった」 & 個人内·肯定 \\
\hline & & & $\begin{array}{l}\text { 逐語: (クラスの皆を集めて)うまく攻められた人? } \\
\text { /はい、Kさんのロングシュート、とても良かったです。今まであんな } \\
\text { ことなかったよね。 } \\
\text { /あれを真似するといいよ。遠くから打つこと。 }\end{array}$ & $\begin{array}{l}\text { 個人内·肯定 } \\
\text { 肯定 }\end{array}$ \\
\hline \multirow[b]{2}{*}{8} & \multirow[b]{2}{*}{$\begin{array}{c}\text { 第9時 } \\
\text { 12月9日 }\end{array}$} & \multirow[b]{2}{*}{$\begin{array}{l}\text { Aさん } \\
\mathrm{H}<ん \\
\mathrm{Nさん}\end{array}$} & 記述「ゴールとボールの間に入ると良い」 & 矯正 \\
\hline & & & $\begin{array}{l}\text { 逐語: (作戦を立てている)あのな、どうやったらうまく守れると思う? } \\
\text { /(児童の意見後に)守る時にどうしてもボール追いかけてっちゃう } \\
\text { から、それは凄く大事なことなんだけど、絶対に忘れちやいけないの } \\
\text { は、ボールとゴールを結んだ線の間に入ること。そうすれば絶対 } \\
\text { シュートできないから。 } \\
\text { /(演示して)シュートされちやうでしょ?だけど、ここにいればシュート } \\
\text { できない。だから自分の背中にいつもゴールを置くようにしなさい。 } \\
\text { そうすると良い守備になるはずだから。 }\end{array}$ & 個人内·矯正 \\
\hline
\end{tabular}


について、当該児童との相互作用が双方向的に営 まれていた。これらは個別の運動学習場面におけ る技能の発揮状況や練習方法についてフィード バックされたもので、加えて、「今の攻めはどう だった？」「ここは、どういう作戦？」などの発 問や、「ここを直したほうがいいんじゃないか な? 」などの誘導的な矯正的フィードバックに よって、児童の自主的な思考や意志決定を保証し ていた。事例 4 と事例 7 につては、クラスすべ ての児童に対する学習指導場面において、児童の 進歩や成長ぶりが教師から紹介され、共感的に集 められるというものであった。

深見・高橋ほか(1997)は、子どもの学習に有効 なフィードバックの指標として次の要素を挙げて いる。(1)技能的学習に対して、具体的な肯定的 · 矯正的フィードバックを積極的に与えること。(2) 子どもに確実に伝達されるような位置、タイミン グ、言葉でフィードバックを与えること。(3)肯定 的フィードバックを与える際には、感情をこめて 共感的にかかわること。(4)具体的なフィードバッ クを与える際には、子どもの印象に残るような吟 味された言葉を適用すること、である。

ここで抽出された 8 つ言葉かけのうち $6 つ$ は、いずれも個別の運動学習場面における技能の 発揮状況や練習方法についてのフィードバックで あり、相互作用が双方向で営まれていることから (1)、(2)の要素に一致するものであった。また、残 りの2つは双方向の相互作用こそ営まれていない ものの、(1)、(2)の要素を含むものであった。(3)と (4)の子どもと共感的にかかわり、印象に残るよう な吟味された言葉を適用するということについて は、本研究の個人内評価による進歩の強調がその 構成要素として挙げられよう。抽出された $8 つ の$

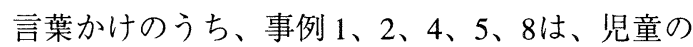
記述分類では個人内肯定以外のカテゴリーに分類 されているが、当該児童との相互作用の文脈を発 話記録によって確認すると、いずれの相互作用に おいても個人内評価による肯定的な言葉かけがな されている。これらのことから、子ども自身の進 歩を強調する個人内評価を意識することによっ て、個々の児童にとって印象に残る教師との相互 作用の機会を増やすことができると考えられる。

\section{IV. 結 論}

本研究は、評価構造を規定する要因としての教 師の言葉かけに着目して、個人内評価を重視した 言葉かけを多く用いることによって、児童の動機 づけを高められるかどうかを、小学校 4 年生 1 学 級の同一教師による体育授業を対象として 1 学期 の対照単元と 2 学期の介入単元で比較検討するこ とを目的とした。

介入単元では、適切に介入が実施された結果、 対照単元と比較して教師の発話記録において明ら かな変化がみられた。1授業あたりのフィード バック回数には大きな変化がなかったが、個人内 評価によるフィードバックが大きく増え、また肯 定的なフィードバックが増えていた。これにとも なって介入単元では教師からの言葉かけを認知し た児童が大きく増加し、また友達からの言葉かけ の認知率も增えていた。このように介入単元では 教師が意図的に言葉かけすることによって授業の 評価構造を変化させることができた。

言葉の認知率が览童の動機づけ、また形成的授 業評価に及ぼす効果を検討するために、動機づけ 変数や形成的授業評価得点がどのように変化した かを分析した結果、教師からの言葉かけを多く認 知した児童ほど、体育授業における課題志向性や マスタリー雲囲気知覚、満足感や能力知覚が向上 するという正の関係と、反対に自我志向性とパ フォーマンス雲囲気知覚が低下するという負の関 係が確認された。これは小学校6年生を対象とし た下田・長谷川ほか (1998）や長谷川・滝川ほか （1997）の結果と一致するものであった。また、 深見・高橋ほか（1996）や、媣見・高橋（2003） と同様に言葉かけの認知率の高い児童ほど形成的 授業評価による学習行動や学習成果を高く評価す るという結果が確認された。

さらに、高マスタリー・低パフォーマンスとい う適応的な体育授業の雲囲気を知覚していた児童 が認知した教師の言葉かけの内容を事例的に検討 した結果、児童の動機づけに有効であると思われ るフィードバックの特徵としては次の点があげら れた。(1)評価基準として個人内評価が採用され、 個別の運動学習にかかわって個人の進歩を強調し た肯定的なフィードバックがなされること、(2)発 問などによって子ども自身に課題を与えるなど、 
相互作用が双方向で営まれること、(3)クラスの全 員の前で進歩を強調したフィードバックを与える ことが有効であった。

以上の分析結果から、小学校4年生の体育授業に おいて子ども自身の進歩を強調する個人内評価に着 目することによって、個々の巟童にとって印象に残 る教師との相互作用の機会が増え、览童の動機づけ が適応的に高められることが示唆された。

本研究では 1 名の教師による 2 単元の介入実験 授業であったが、本研究で活用した教授方略が児 童の動機づけに対して一定の効果をもつことが確 認できた。しかし今後の課題としては、教師の言 葉かけに関する教授方略を実行するために、教師 はどのような運動学習に関する専門的知識を持っ ていなければならないか、またこの教授方略はど の年齢までの児童・生徒に有効であるのかなどに ついて検証を続ける必要がある。これらの知見を 蓄積して教授能力向上のための教師養成・研修プ ログラムに活用していきたい。

\section{注}

（注1）本研究では、評価基準とは、相対評価、個 人内評価、絶対評価など達成行動の成功・失敗 を測定するものさしにかかわる要因を意味す る。相対評価は他者との相対比較によって、個 人内評価は個人の過去の成績や他の領域の成績 との比較によって、絶対評価は、評価者が設定 した何らかの内容的な基準との比較によって達 成行動の評価が行われる。更に、絶対評価は、 外的・客観的に設定された達成目標との比較によ る到達度評価と、評価者が個人的に設定した内的 な基準との比較による認知評価とに区別される。

(注2）単元計画及び指導案は、当該学校ならびに 担任教師が作成しているものにしたがった。器 械運動では、前転、後転の基本的な技から開脚 前転や側方倒立回転までの発展的な技の学習が 目標とされ、一般にいわれる「めあて学習」の 学習過程が用いられた。ポートボールでは、3 チームに分かれての 5 対 5 のゲームを中核に、 パス、ドリブル、シュート等の技術の学習が目 標とされ、単元前半と後半とで総当たり戦が計 画・実施された。

\section{引用・参考文献}

Ames,C (1984) Conceptions of motivation within competitive and noncompetitive: A cognitive motivational analysis. In R.Ames \& C.Ames (Eds.), Research on motivation in education: vol.1.Student motivation. New York: Academic Press. Pp.177-207

Ames, C (1992) Classroom: Goals Structures, and student motivation. Journal of Educational Psychology, 84, 261-271.

Ames, C. \&Archer, J. (1988) Achievement goals in the classroom: Students' learning strategies and motivation processes. Journal of Educational Psychology, 80, 260-267.

Biddle,S., Cury,F., Godas,M., Sarrazin,P., Famose,J.P, \& Durand,M. (1995) Development of scales to measure perceived physical education class climate: A cross national project. British Journal of Educational Psychology, 65, 341-358.

Butler, R. (1987) Task-involving and ego- involving properties of evaluation: Effect of different feedback conditions on motivational perceptions, interest, and, performance. Journal of Educational Psychology, 79, 474-482.

Butler, R. (1988) Enhancing and undermining intrinsic motivation: The effect of task-involving and ego involving evaluation on interest and performance. British Journal of Educational Psychology, 58, 114

Butler, R. (1990) The effects of mastery and competitive conditions on self-assessment at different ages. Child Development, 61, 201-210.

Butler, R. (1992) What young people want to know when: Effects of mastery and ability goals on interest in different kinds of social comparisons. Journal of Personality and Social Psychology, 62, 934-943.

Deci, E.L., Nezlek, J. \& Sheinman, L. (1981) Characteristics of the rewarder and intrinsic motivation of the rewardee. Journal of Personality and Social Psychology, 40, 1-10

Duda, J.L. (1989) The relationship between task and ego orientation and the purpose of sport among 
male and female high school athletes. Journal of Sport and Psychology, 11, 318-335.

Duda, J.L. (1992) Motivation in sport settings: A goal perspective approach. In G.C.Robert (Ed.), Motivation in sport and exercise, Champaign, IL: Human Kinetics, pp.51-91.

Duda, J.L. (1996) Maximizing motivation in sport and physical education among children and adolescents: The case for greater task involvement. Quest, 48, 290-302.

Duda, J.L., Fox, K., Biddle, S.H., \&Armstrong, N. (1992) Children's achievement goals and beliefs about success in sport. British Journal of Educational Psychology, 62, 313-320.

Duda, J.L. \&Nicholls, J.G. (1992) Dimension of achievement motivation in schoolwork and sport. Journal of Educational Psychology, 84, 290-299.

Dweck, C.S. (1992) Motivational processes affecting learning. American Psychologist, 41, 1040-1048.

Fox, K., Goudas, M., Biddle, S,H. ,Duda, J.L. \& Armstrong, N. (1994) Children's task and ego goals profiles in sport. British Journal of Educational Psychology, 64, 253-261.

深見英一郎・高橋健夫 ·日野克博 - 芳野聡 (1997) 体育授業における有効なフィードバック行動 に関する検討：特に,子どもの受けとめかた や授業評価との関係を中心に体育学研究 42,167-179.

深見英一郎・高橋健夫 (2003) 器械運動における有 効な教師のフィードバックの検討一学習行動 に応じたフィードバックと子どもの受けとめ かたとの関係を通して一、スポーツ教育学研 究23(2) : 95-112.

Harackiewicz, J.M., Abrahams, S., \&Wageman, R. (1987) Performance evaluation and intrinsic motivation: The effects of evaluative focus, rewards, and achievement orientation. Journal of Personality and Social Psychology, 54, 1015-1023.

長谷川悦示·下田和史・滝川孝八 (1998) 小学生体 育授業の評価構造と児童の動機づけ(1)：教 師の言葉かけに対する览童の反応と授業の雾 囲気知覚及び目標志向性との関係, 日本ス ポーツ教育学会第18回大会, 静岡大学.
長谷川悦示 - 高橋健夫 - 松本富子 - 浦井孝夫 (1995) 小学校体育授業の形成的授業評価票及 び診断基準作成の試み スポーツ教育学研究 14(2)91-101

長谷川悦示・滝川孝八 ·下田和史(1997)体育の授業 構造が小学生の目標志向性に及ぼす影響, 日本 スポーツ教育学会第17回大会, 立正大学.

長谷川悦示 · 滝川孝八 · 鈴木武文 · 下田和史 (1999) 小学生の体育授業における目標志向 性. 群馬大学教育学部紀要 芸術 - 技術 - 体 育・生活科学編, 34：175-187.

伊藤豊彦 (1996) スポーツにおける目標志向性に関 する予備的検討. 体育学研究 41:261-272.

鹿毛雅治(1996)内発的動機づけと教育評価風間 書房：東京.

Kavussanu, M., \& Roberts, G.C. (1996) Motivation in physical activity contexts: The relationship of perceived motivational climate to intrinsic motivation and self-efficacy. Journal of Sport\& Exercise Psychology, 18, 264-280.

McKiddie, B., \& Maynard, I.W. (1997) Perceived competence of schoolchildren in physical education. Journal of Teaching in Physical Education, 16, 324-339.

Nicholls, J.G (1984) Achievement motivation: Concepts of ability, subjective experience, task choice, and performance. Psychological Review, 91, 328-346.

Papaioannou, A. (1994) Development of a questionnaire to measure achievement orientations in physical education. Research Quarterly for Exercise and Sport, 65, 11-20.

Roberts, G.C. (1992) Motivation in sport and exercise: Conceptual constraints and convergence. In G.C.Robert (Ed.), Motivation in sport and exercise, Champaign, IL: Human Kinetics, pp.3-29

Roberts, G.C., \& Treasure, D.C. (1995) Achievement goals, Motivational climate and achievement strategies and behaviors in sport. International Journal of Sport Psychology, 26, 64-80.

Seifriz, J.J., Duda, J.L. \& Chill. (1992) The relationship of perceived motivational climate to intrinsic motivation and beliefs about success in basketball. 
Journal of Sport \& Exercise Psychology, 14, 375391.

下田和史・長谷川悦示・滝川孝八(1998) 小学生体 育授業の評価構造と児童の動機づけ(2) : 教 師の言葉かけが児童の授業の雲囲気知覚と情 意変数に及ぼす影響，日本スポーツ教育学会 第18回大会, 静岡大学.

高橋健夫 ·岡沢祥訓 · 中井隆司 - 芳本真 (1992) 体 育授業における教師行動に関する研究 36(3): 193-208.

高橋健夫・歌川好夫 ·吉野聡・日野克博 ·深見英 一郎・清水茂幸 (1996) 教師の相互作用及びそ の表現のしかたが子どもの形成的授業評価に 及ほす影響 スポーツ教育学研究16(1)1323.

滝川孝八・長谷川悦示 (1996) 小学生の体育授業 に㧍ける目標志向性，日本スポーツ教育学会 第16回大会, 福井大学。
Treasure, D.C. (1997) Perceptions of the motivational climate and elementary school children's cognitive and affective response. Journal of Sport \& Exercise Psychology, 19,278-290.

Walling, M.D., \& Duda, J.L. (1995) Goal and associations with beliefs about success in and perceptions of the purpose of physical education. Journal of Teaching in Physical Education, 14, 140-156.

Walling.M.D. Duda, J.L., Chi, L. (1993) The perceived motivational climate in Sport investment, and participation motivation to task and ego orientation. International Journal of Sport Psychology, 25, 4-18.

White, S.A., \& Duda, J.L. \& (1994) The relationship of gender, level of sport investment, and participation motivation to task and ego orientation. International Journal of Sport Psychology, 25, 4-18.

平成 16 年 4 月 30 日 受付

平成 16 年 6 月 28 日 受理

